\title{
STRATEGI MAHASISWA PROFESI NERS DALAM MENGHADAPI UJI KOMPETENSI NERS
}

\author{
Henny Syapitri ${ }^{1}$, Johansen Hutajulu ${ }^{2}$ \\ ${ }^{1,2}$ Universitas Sari Mutiara Indonesia \\ Email : heny_syahfitri86@yahoo.com
}

\begin{abstract}
ABSTRAK
Munculnya sistem pendidikan tinggi keperawatan di Indonesia, diharapkan dapat menghasilkan lulusan yang memiliki sikap, pengetahuan dan keterampilan profesional keperawatan sehingga berkemampuan untuk menjalankan perannya dalam memberikan pelayanan keperawatan. Pemerintah Indonesia telah menyelenggarakan sistem penjaminan mutu pendidikan tinggi bidang kesehatan dintaranya adalah uji kompetensi. Uji kompetensi merupakan kemampuan seseorang yang dapat diobservasi yang mencakup pengetahuan, ketrampilan dan sikap dalam menyelesaikan suatu pekerjaan atau tugas dengan standart kinerja performance yang ditetapkan. Menurut data dari Asosiasi Institusi Pendidikan Ners Indonesia (AIPNI) rata-rata kelulusan UKOM Ners pada bulan Oktober Tahun 2018 hanya mencapai 35,3\%. Data Universitas Sari Mutiara Indonesia angka kelusan Uji Kompetensi Ners tahun 2018 justru mengalami peningkatan yaitu sebesar $82 \%$. Berdasarkan data tersebut perlu diidentifikasi persiapan mahasiswa dalam menghadapi uji kompetensi. Tujuan penelitian ini adalah untuk mengidentifiasi strategi mahasiswa Profesi Ners dalam menghadapi Uji Kompetensi Ners. Jenis penelitian ini adalah penelitian deskriptif. Populasi dalam penelitian ini adalah mahasiswa profesi Ners Universitas Sari Mutiara Indonesia. Sampel dalam penelitian ini sejumlah 72 orang dengan menggunakan tehnik total populasi. Instrument yang digunakan dalam penelitian ini adalah kuesioner yang dibuat dan diuji oleh peneliti sendiri. Uji validitas dilakukan ditempat yang berbeda, hasil Validitas dan reliabilitas diuji dengan korelasi Pearson Product Moment dan Cronbach's alpha, dengan nilai Cronbach Alpha lebih besar dari 0,721. Analisis data yang digunakan adalah analisis univariat. Hasil penelitian menunjukkan mayoritas mahasiswa memiliki referensi yaitu sebesar $(88,9 \%)$, mayoritas mahasiswa memahami blueprint soal dengan Baik yaitu sebesar (77,8\%), seluruh mahasiswa (100\%) mengikuti bimbingan belajar intensif dikampus maupun bimbingan belajar secara online, mahasiswa (100\%) mengikuti tryout lokal maupun tryout nasional. Institusi pendidikan ners memiliki tanggung jawab besar dalam mendukung kelulusan mahasiswanya dari ukom. Sehingga institusi diharapkan memberikan pembinaan kepada mahasiswanya guna meningkatkan angka kelulusan ukom dan meningkatkan kualitas lulusan.
\end{abstract}

Kata kunci : Strategi, Uji kompetensi, Mahasiswa ners 


\title{
STRATEGY OF NERS PROFESSIONAL STUDENTS IN FACING THE NERS COMPETENCY TEST
}

\begin{abstract}
The emergence of the nursing higher education system in Indonesia is expected to produce graduates who have the attitudes, knowledge and professional skills of nursing so that they are able to carry out their role in providing nursing services. The Indonesian government has implemented a higher education quality assurance system in the health sector, including a competency test. Competency test is a person's ability that can be observed which includes knowledge, skills and attitudes in completing a job or task with a set performance performance standard. According to data from the Association of Indonesian Nurse Education Institutions (AIPNI), the average UKOM Nurse graduation in October 2018 only reached 35.3\%. Data from the Sari Mutiara Indonesia University, the pass rate for the 2018 Nurse Competency Test actually increased by $82 \%$. Based on these data, it is necessary to identify student preparation in facing competency tests. The purpose of this study was to identify the strategies of the Nurse Profession students in facing the Nurse Competency Test. This type of research is descriptive research. The population in this study were students of the Nurse Profession at Sari Mutiara Indonesia University. The sample in this study were 72 people using the total population technique. The instrument used in this study was a questionnaire that was created and tested by the researchers themselves. The validity test was carried out in different places, the results of validity and reliability were tested with the correlation between Pearson Product Moment and Cronbach's alpha, with a Cronbach Alpha value greater than 0.721. The data analysis used was univariate analysis. The results showed that the majority of students had a reference, namely (88.9\%), the majority of students understood the blueprint of the questions well, which was (77.8\%), all students (100\%) attended intensive tutoring at campus and online tutoring, students (100\%) participate in local and national tryouts. Nurse education institutions have a big responsibility in supporting the graduation of students from UKOM. So that the institution is expected to provide guidance to students in order to increase the graduation rate of UKOM and improve the quality of graduates.
\end{abstract}

Keywords: Strategy, Competency Test, Ners Student

\section{PENDAHULUAN}

Menurut Undang-Undang No. 382014 Perawat yang profesional dapat dihasilkan melalui pendidikan yang bermutu. Seorang calon perawat harus melewati dua tahap pendidikan yaitu tahap pendidikan akademik yang lulusannya mendapat gelar Sarjana Keperawatan (S.Kep) dan tahap pendidikan profesi yang lulusannya mendapat gelar Ners (Sumoked, 2019).

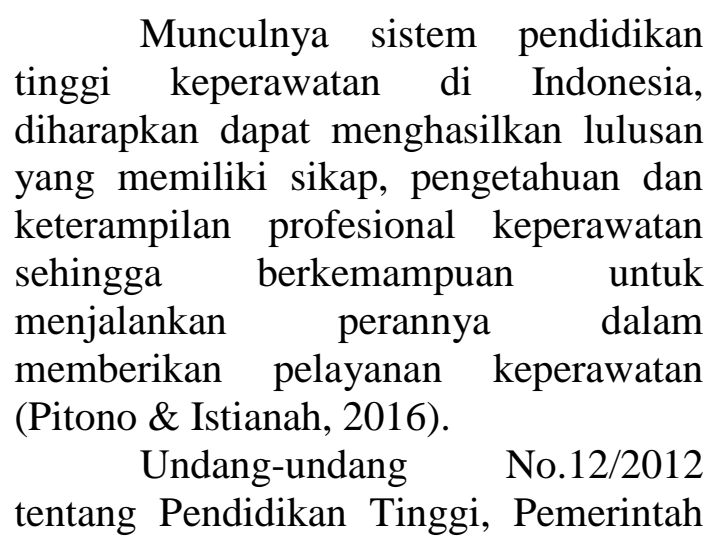


Indonesia telah menyelenggarakan sistem penjaminan mutu pendidikan tinggi bidang kesehatan dintaranya adalah uji kompetensi, kebijakan utama Pemerintah dalam melaksanakan penjaminan mutu pendidikan tinggi yaitu penyelenggaraan uji kompetensi secara nasional (Kemenristek Dikti, 2016).

Uji kompetensi merupakan kemampuan seseorang yang dapat diobservasi yang mencakup pengetahuan, ketrampilan dan sikap dalam menyelesaikansuatu pekerjaan atau tugas dengan standart kinerja performance yang ditetapkan (Yulifah, 2017).

Uji kompetensi (ukom) ners nasional merupakan uji yang digunakan untuk menstandardisasi kompetensi perawat Indonesia saat ini. Perawat dikatakan kompeten jika lulus ukom nasional. Untuk dapat meningkatkan kompetensi perawat, Asosiasi Institusi Pendidikan Ners Indonesia (AIPNI) mengeluarkan beberapa himbauan kepada anggotanya untuk mempersiapkan dan membina mahasiswanya sehingga siap untuk mengikuti ukom nasional dengan hasil yang maksimal (lulus) (AIPNI, 2019). Akan tetapi, angka kelulusan ukom nasional perawat (ners) dari tahun ke tahun masih cukup rendah dan terus menurun dari tahun 2016 hingga akhir tahun 2018. Sementara jumlah peserta ukom ners dari tahun ke tahun terus bertambah. Hal ini dikarenakan peserta yang tidak lulus ukom dari tahun ke tahun terus bertambah dan menumpuk pada periode selanjutnya (Dikti, 2019).

Data Nasional kelulusan Uji Kompetensi Ners Indonesia setiap tahunnya mengalami penurunan, tahun 2016 tingkat kelulusan periode VI sebesar $47,16 \%$ dinyatakan kompetensi, tahun 2017 periode VII sebesar $44.62 \%$ dinyatakan kompeten dan periode VIII tahun 2017 diperoleh sebesar $41.12 \%$ dinyatakan lulus dengan kompeten, kemudian pada tahun 2018 hanya mencapai kelulusan 35,3\% (Kemenristek DIKTI, 2019).

Institusi memiliki peran penting dalam mempersiapkan kelulusan mahasiswanya untuk menghadapi uji kompetensi. Persiapan tersebut dapat dimulai sejak semester awal. Beberapa cara yang telah diterapkan di Prodi Ners USM Indonesia ialah dengan menerapkan ujian tengah semester dan ujian akhir semester dengan menggunakan soal vignette dan sudah terintegrasi dengan komputer. Sehingga mahasiswa tidak merasa asing lagi dengan soal-soal yang berbasis problem solving. Untuk mendukung hal tersebut, maka dosen pengajarnya juga harus dibekali dengan kemampuan item development dan item review. Selain itu, mewajibkan mahasiswa untuk mengikuti tryout internal yang diadakan secara gratis dilingkungan kampus sebagai evaluasi dari kegiatan bimbingan belajar intensif yang dilakukan institusi guna memantapkan kesiapan mahasiswa.

Data Universitas Sari Mutiara Indonesia angka kelusan Uji Kompetensi Ners justru memiliki peningkatan selama tiga tahun terakhir, pada tahun 2016 angka kelulusan mahasiswa sebesar $55 \%$, tahun 2017 sebesar $82 \%$ dan tahun 2018 mengalami peningkatan sebesar $82 \%$. Berdasarkan data tersebut perlu diidentifikasi persiapan mahasiswa dalam menghadapi uji kompetensi, salah satunya adalah strategi persiapan ujian. Strategi belajar dapat dilaksanakan mahasiswa dalam menghadapi ujian perilaku yaitu kepemilikan referensi, cara mempelajari referensi, belajar kelompok, bimbingan belajar, keteraturan belajar, kegiatan persiapan dalam menghadapi ujian, dan kondisi lingkungan belajar. Dalam strategi persiapan ujian mahasiswa juga harus memperhatikan aspek intelegensi, emosi 
dan spiritual sehingga tercipta sebuah keseimbangan untuk meraih tujuan.

Tujuan penelitian ini adalah untuk mengidentifiasi strategi mahasiswa Profesi Ners dalam menghadapi Uji Kompetensi Ners di Universitas Sari Mutiara Indonesia Medan

\section{METODE PENELITIAN}

Jenis penelitian ini adalah penelitian deskriptif. Penelitian ini dilakukan di Program Studi Ners Universitas Sari Mutiara Indonesia pada bulan Maret-Agustus 2019. Populasi dalam penelitian ini adalah mahasiswa profesi Ners Universitas Sari Mutiara
Indonesia. Sampel dalam penelitian ini sejumlah 72 orang dengan menggunakan tehnik total populasi.

Instrument yang digunakan dalam penelitian ini adalah kuesioner yang dibuat dan diuji oleh peneliti sendiri. Uji validitas dilakukan ditempat yang berbeda, dengan jumlah sampel 30 orang. Hasil Validitas dan reliabilitas diuji dengan korelasi Pearson Product Moment dan Cronbach's alpha, dengan nilai Cronbach Alpha lebih besar dari 0,721 . Artinya, instrumen tersebut dalam kategori sangat tinggi dan dinyatakan reliabel untuk digunakan dalam penelitian. Analisis data yang digunakan adalah analisis univariat.

HASIL PENELITIAN

Tabel 1

Karakteristik Responden Berdasarkan Usia dan Jenis Kelamin $(n=72)$

\begin{tabular}{clcc}
\hline No & \multicolumn{1}{c}{ Karakteristik } & Frekuensi & Persentase \\
\hline 1 & Usia & & \\
& 22 Tahun & 6 & $8,3 \%$ \\
& 23 Tahun & 34 & $47,2 \%$ \\
& 24 Tahun & 22 & $30,6 \%$ \\
& 25 Tahun & 10 & $13,9 \%$ \\
\hline 2 & Jenis Kelamin & & \\
& Laki -laki & 28 & $38,9 \%$ \\
& Perempuan & 44 & $61,1 \%$ \\
\hline
\end{tabular}

Berdasarkan tabel 1 dapat dilihat dari 72 responden yang diteliti mayoritas responden usia 23 Tahun tahun sebanyak 34 orang $(47,2 \%)$, berdasarkan jenis kelamin mayoritas perempuan sebanyak 44 orang $(61,1 \%)$.

Tabel 2

\section{Distribusi Stategi Mahasiswa Berdasarkan Kepemilikan Referensi}

$(\mathbf{n}=72)$

\begin{tabular}{lcc}
\hline \multicolumn{1}{c}{ Kepemilikan Referensi } & Frekuensi & Persentase \\
\hline Ada & 64 & $88,9 \%$ \\
Tidak ada & 8 & $11,1 \%$ \\
\hline
\end{tabular}

Berdasarkan tabel 2 dapat dilihat dari 72 responden yang diteliti mayoritas responden memiliki referensi sebanyak 64 orang $(88,9 \%)$. 
Tabel 3

Distribusi Stategi Mahasiswa

Berdasarkan Pemahaman Blueprint Soal

$(n=72)$

\begin{tabular}{lcc}
\hline Pemahaman Blueprint Soal & Frekuensi & Persentase \\
\hline Baik & 56 & $77,8 \%$ \\
Cukup & 11 & $15,3 \%$ \\
Kurang & 5 & $0,9 \%$ \\
\hline
\end{tabular}

Berdasarkan tabel 3 dapat dilihat dari 72 responden yang diteliti mayoritas pemahaman responden terhadap blueprint soal Baik yaitu sebanyak 56 orang $(77,8 \%)$.

\section{Tabel 4}

Distribusi Stategi Mahasiswa

Berdasarkan Keikutsertaan Bimbingan Belajar

$(\mathbf{n}=72)$

\begin{tabular}{lcc}
\hline Keikutsertaan Bimbingan Belajar & Frekuensi & Persentase \\
\hline Ya & 72 & $100 \%$ \\
Tidak & 0 & $0 \%$ \\
\hline
\end{tabular}

Berdasarkan tabel 4 dapat dilihat dari 72 responden yang diteliti seluruhnya mengikuti Bimbingan belajar intensif dikampus maupun bimbingan belajar secara online.

Tabel 5

Distribusi Stategi Mahasiswa Berdasarkan Keikutsertaan Tryout $(\mathbf{n}=72)$

\begin{tabular}{lcc}
\hline \multicolumn{1}{c}{ Keikutsertaan TryOut } & Frekuensi & Persentase \\
\hline Ya & 72 & $100 \%$ \\
Tidak & 0 & $0 \%$ \\
\hline
\end{tabular}

Berdasarkan tabel 5 dapat dilihat dari 72 responden yang diteliti seluruhnya mengikuti tryout lokal maupun tryout nasional.

\section{PEMBAHASAN}

\section{a. Kepemilikan Referensi}

Mempelajari soal-soal tes Uji

Kompetensi Ners Indonesia dari buku atau sumber lainnya akan sangat membantu dalam mempersiapkan diri. Dengan belajar soal Uji Kompetensi Ners Indonesia dapat juga memberikan gambaran materi dan tipe soal yang akan anda hadapi dalam Uji Kompetensi Ners
Indonesia.Oleh karena itu kepemilikan referensi terakit Uji Kompetensi Ners Indonesia sangat diperlukan (Adiwidya, 2015).

Hasil penelitian menunjukkan mayoritas mahasiswa Profesi Ners Universitas Sari Mutiara Indonesiamemiliki referensi yaitu sebesar $88,9 \%$.

Pembelajaran soal sebaiknya diikuti materi tes. Bagaimanapun untuk 
memecahkan soal kasus Uji Kompetensi Ners Indonesia membutuhkan pemahaman referensi materi yang kuat. Sebagai persiapan yang optimal dalam menghadapi Uji Kompetensi Ners Indonesia mahasiswa diharapkan dapat mulai belajar atau membuka kembali materi yang sudah pernah dipelajari pada tahap akademik serta menghindari istilah belajar dengan sistem kebut semalam.

Penggunaan referensi yang terstandar sangat diperlukan untuk menjamin pemahaman yang sama untuk peserta Uji Kompetensi Ners Indonesia se Indonesia. Dalam pembahasan soal-soal Uji Kompetensi Ners Indonesia juga peserta ujian harus bisa mengesampingkan pengalaman pribadi karena soal Uji Kompetensi Ners Indonesia dikerjakan berdasarkan data yang ada pada soal (Roimah \& Amaliya, 2016).

\section{b. Pemahaman Blueprint Soal}

Pemahanman peserta uji kompetensi tentang blue print uji kompetensi yang meliputi butir soal, tinjauan, jumlah soal terbanyak dan strategi menjawab soal berdasarkan pemahaman yang baik dengan soal uji kompetensi. Pemahaman tentang blueprint soal bertujuan untuk memberikan panduan dalam pengembangan materi uji yang benar secara proporsional dari pencapaian kompetensi, materi yang sesuai dan dengan instrumen yang tepat. Dengan pola pengembangan blue print ini akan menghasilkan butir soal yang sesuai dengan kompetensi yang diharapkan (Nugroho, 2016).

Hasil penelitian menunjukkan mayoritas mahasiswa Profesi Ners Universitas Sari Mutiara Indonesia sudah memahami blueprint soal dengan Baik yaitu sebesar $77,8 \%$. Data tersebut menunjukkan bahwa sejak pertama mengikuti Uji Kompetensi Ners Indonesia hingga akhir tahun 2018 mahasiswa Program Studi Ners USM Indonesia sudah mendapatkan informasi tentang kisi-kisi UKNI dengan mengikuti kegiatan sosialisasi yang dipaparkan oleh dosen maupun kegiatan seminar terkait blueprint soal uji kompetensi.

Kholifah \& Kusumawati (2016) yang mengatakan bahwa hambatan yang menjadi penyebab kegagalan lulusan ners dalam UKNI adalah ketidaktahuan tentang konsep UKNI, terutama tentang kisikisi UKNI atau blueprint.Blueprint uji kompetensi sangat penting diketahui oleh peserta uji kompetensi karena berisi ruang lingkup soal yang akan diujikan sehingga menjadi acuan dalam belajar dan menjadi focus dalam soal yang akan diujikan. Kisi-kisi atau blueprint Uji Kompetensi Ners Indonesia harus disosialisasikan kepada lulusan ners sehingga lulusan ners benar-benar mempersiapkan apa saja yang akan diujikan di Uji Kompetensi Ners Indonesia (Nugroho, 2016).

Pengetahuan tentang blueprint soal (kisi kisi UKNI) merupakan salah satu bagian penting dalam proses persiapan menghadapi UKNI. Septiari (2014) meyebutkan bahwa pentingnya mengetahui tentang blueprint merupakan kewajiban peserta UKNI, dimana salah satunya adalah peserta harus mengetahui dan memahami metode, mekanisme dan nilai batas kelulusan. Dengan demikian blueprint dapat digunakan sebagai salah satu strategi untuk lulus Uji Kompetensi.

\section{c. Keikutsertaan Bimbingan Belajar}

Uji Kompetensi Ners Indonesia merupakan standardisasi kompetensi bagi perawat di Indonesia. Kemampuan mahasiswa untuk mengikuti uji kompetensi harus dipersiapkan sejak awal, yaitu saat mahasiswa masih menempuh pendidikan. Namun, jika setelah mahasiswa selesai menempuh pendidikan dan hal tersebut dirasa belum 
cukup, maka dapat dilakukan strategi lain. Salah satu jalan yang bisa ditempuh adalah dengan memberikan bimbingan belajar intensif (Choeron, R. C, 2020).

Bimbingan intensif penting diberikan oleh institusi kepada mahasiswa sebelum pelaksanaan ukom nasional. Melalui bimbingan intensif mahasiswa tidak hanya diajarkan bagaimana cara memecahkan kasuskasus yang ada dalam soal, tetapi juga bagaimana menemukan dan menerapkan pola penyelesaian masalah dari masingmasing departemen yang diujikan. Polapola pemecahan masalah merupakan hal terpenting yang harus dikuasai oleh mahasiswa, karena setiap departemen yang diujikan memiliki pola yang berbeda-beda.

Hasil penelitian menunjukkan seluruh mahasiswa Profesi Ners Universitas Sari Mutiara Indonesia mengikuti Bimbingan belajar intensif dikampus maupun bimbingan belajar secara online. Bimbingan belajar intensif telah terbukti meningkatkan kesiapan mahasiswa dalam menghadapi uji kompetensi nasional, walaupun dalam proses akademiknya mahasiswa telah diarahkan pada pemecahan kasus.

Hal ini terjadi karena mahasiswa Program Studi Ners USM Indonesia mengadakan kelas bimbingan belajar secara gratis. Dengan demikian, seluruh mahasiswa Program Studi Ners USM Indonesia diwajibkan mengikuti kegiatan bimbingan belajar intensif dikampus. Kegiatan bimbingan intensif ini merupakan syarat bagi mahasiswa untuk bisa didaftarkan/mengikuti Uji Kompetensi Ners Indonesia.

Terbukti angka kelusan Uji Kompetensi Ners di USM Indonesia mengalami peningkatan selama tiga tahun terakhir, pada tahun 2016 angka kelulusan mahasiswa sebesar 55\%, tahun 2017 sebesar 82\% dan tahun 2018 mengalami peningkatan sebesar $82 \%$.

\section{d. Keikutsertaan Tryout}

Sesuai dengan amanat UU 38 Tahun 2014 pasal 16, mahasiswa Keperawatan pada akhir proses pendidikan harus mengikuti Uji Kompetensi Nasional. Selanjutnya mahasiswa sebelum mengikuti Uji Kompetensi Nasional akan mengikuti Try out Uji Kompetensi Ners yang diselenggarakan oleh APINI, tujuan nya adalah untuk memberikan pengalaman dan mempersiapkan mental serta berlatih dalam menghadapi Uji Kompetensi yang terstandar (UndangUndang RI, 2014).

Pada hasil try out Nasional, setiap mahasiswa mendapatkan lembaran hasil yang dilengkapi dengan 7 tinjauan pada soal-soal UKNI. Dimana dalam 7 tinjauan tersebut terlihat item mana yang perlu di tingkatkan oleh para mahaiswa sebagai persiapan untuk ujian sebenarnya yaitu UKNI.

Mahasiswa yang telah mengikuti try out akan lebih siap mengerjakan soal ujian dari pada mahasiswa yang tidak mengikuti try out karena mereka telah memiliki gambaran soal sehingga hasilnya akan lebih baik. TO UKNI mampu memberikan gambaran mengenai model soal yang akan digunakan pada saat ujian kompetensi yang sebenarnya. Selain itu, TO dapat menjadi bahan evaluasi peserta didik untuk mengetahui kesiapan dalam mengikuti UKNI. TO merupakan suatu mekanisme yang digunakan sebagai sebuah latihan bagi seseorang sebelum melaksanakan ujian yang sesungguhnya. TO hanyalah sebagai media untuk berlatih mengerjakan soal. Semakin sering berlatih, peserta didik akan semakin siap untuk menghadapinya karena kesuksesan itu dimulai dari banyaknya latihan atau persiapan yang matang (Kariasa et al, 2013).

Hasil penelitian menunjukkan seluruh mahasiswa Profesi Ners USM 
Indonesia mengikuti tryout lokal maupun tryout nasional. Hal ini dikarenakan Program Studi Ners USM Indonesia mewajibkan mahasiswa untuk mengikuti tryout internal yang diadakan secara gratis dilingkungan kampus sebagai evaluasi dari kegiatan bimbingan belajar intensif. Kegiatan tryout internal dilaksanakan setiap hari sabtu selama 3 bulan.Hasil analisis internal yang dilakukan di program studi menunjukkan bahwa mahasiswa yang lulus try out internal maupun try out nasional memberikan dampak positif terhadap kelulusan uji kompetensi.

Hal ini sejalan dengan hasil penelitian seelumnya yang mengatakan bahwa try out yang diikuti sebelumnya oleh mahasiswa turut berperan dalam kelulusan ukom. Mahasiswa yang lulus try out khususnya try out nasional yang diselenggarakan oleh APINI memberikan dampak positif terhadap kelulusan ukom (Abdillah, 2016; Lukmanulhakim \& Pusporini, 2018).

Hal ini juga sesuai dengan apa yang telah diungkapkan oleh Wijaya dkk (2017), bahwa kaitan hasil try out UKNI dapat dijadikan evaluasi terhadap akar permasalahan keberhasilan capaian hasil UKNI dan dapat dicarikan solusi yang tepat sebagai bentukpenjaminan mutu penyelenggaraan pendidikan keperawatan yang berkelanjutan.

\section{KESIMPULAN}

Hasil penelitian menunjukkan mayoritas mahasiswa memiliki referensi yaitu sebesar (88,9\%), mayoritas mahasiswa memahami blueprint soal dengan Baik yaitu sebesar $(77,8 \%)$, seluruh mahasiswa (100\%) mengikuti bimbingan belajar intensif dikampus maupun bimbingan belajar secara online, mahasiswa $(100 \%)$ mengikuti tryout lokal maupun tryout nasional.

\section{UCAPAN TERIMAKASIH}

Ucapan terima kasih kami sampaikan kepada Universitas Sari Mutiara Indonesia yang telah memberikan dukungan dana dalam penelitian ini.

\section{DAFTAR PUSTAKA}

Abdillah, A. (2016). Analisis faktorfaktor yang mempengaruhi kelulusan uji kompetensi ners Indonesia. Jurnal Penelitian Administrasi Publik, Vol. 2(2): Hal. 373-380

Adiwidya. (2015). Panduan Lulus UKNI Uji Kompetensi Ners Indonesia. Jakarta. Visimedia Pustaka

AIPNI-AINEC (2015). Kerangka Acuan Kerja Tryout Uji Kompetensi Ners TIM Komponen Health Profesional Educatian Quality (HPEQ Project)

Choeron, R. C., \& Metrikayanto, W. D. (2020). MENINGKATKAN KESIAPAN UJI KOMPETENSI NERS MELALUI BIMBINGAN INTENSIF: Improving The Readiness of NERS Competence Test Through Intensive Guidance. Jurnal Ilmiah Keperawatan (Scientific Journal of Nursing), 6(1), 143-147.

Kemenristek DIKTI. (2017). Data Statistik Pendaftar lulus dan tidak lulus. Registrasi Online Uji Kompetensi NERS. Melalui: http://ukners.dikti.go.id/pages/statist $\underline{\text { iik_lulus }}$

Kemensristek. (2016). Implementasi Uji Kompetensi Nasional bidang Kesehatan sebagai Langkah Konkrit Penjaminan Mutu : Ditjen Dikti. 
Lukmanulhakim \& Puspitorini, LS. (2018). Analisis faktor yang mempengaruhi capaian kelulusan uji kompetensi ners Indonesia Program Profesi Ners. Jurnal Cakrawala Pendidikan, Vol. 2(2): Hal. 306-320

Nugroho, A. S. (2016). Gambaran Persepsi Mahasiswa Profesi PSIK FK UGM Tentang Uji Kompetensi Ners Indonesia. Universitas Gadjah Mada.

Permenkes RI. (2013). Tentang Uji Kompetensi Bagi Mahasiswa Perguruan Tinggi Bidang Kesehatan.

Pitono \& Istianah (2016). Lulusan Ners STIKes Rajawali Bandung. PROSIDING Seminar Nasional \& Lokakarya Uji Kompetensi Tenaga Kesehatan.. 978-602-14422-7-2. pp: 137.

PPNI. (2015). Standar Kompetensi Perawat Indonesia. Jakarta : Pengurus Pusat', pp.36-40.

Program Studi Ners, Universitas Sari Mutiara Indonesia

Rohimah, Annisa'I \& Amaliya, Mida Ayu. (2016). Taktis Uji Kompetensi Keperawatan Ners. Jakarta. Edu
Penguin.

Septiari, B.B (2014). Uji Kompetensi Ners Indonesia (UKNI). Yogyakarta: Nuha Medika

Sumoked, A. (2019) Hubungan kecemasan menghadapi ujian skills labdengan prestasi yang dicapai pada mahasiswa FK Universitas Gajah Mada. 'Mahasiswa Semester III Program Studi Ilmu Klinik Keperawatan', 7.

Undang-Undang RI (2012) No.12 Tentang Pendidikan Tinggi

Undang-Undang RI (2014) No.38 Tentang Praktik Keperawatan

Wijaya, D., Sulstyorini, L., \& Wantiyah (2017). Analisis Hasil Try Out Uji Kompetensi Ners Berbasis PDCA di Program Studi Ilmu Keperawatan Universitas Jember. PRO-SIDING Seminar Nasional \& Lokakarya Uji Kompetensi Tenaga Kesehatan. LPUK-NAKES \& UNPAD. ISBN No.978-602-14422-7-2. Pp.91-105

Yulifah. (2017). Sumber stres dan mekanisme koping mahasiswa ilmu keperawatan universitas islam negeri syarif hidayatullah jakarta dalam pembelajaran klinik 